\title{
FOOTLOOSE AND FANCY FREE? STATE AID AFTER BREXIT
}

\author{
Stephanie Switzer*
}

There is a perception in certain quarters that EU state aid law acts as a barrier to the UK's ability to pursue an effective industrial policy. Indeed, while the level of state aid provided by the UK is low, ${ }^{1}$ members of the current UK government and Labour's Jeremy Corbyn have framed the EU state aid regime as potentially limiting the UK's ability to support British business. ${ }^{2}$ The UK's decision to leave the EU has thus led some commentators to opine that Brexit will allow the UK to provide greater support to domestic industry. ${ }^{3}$

This article evaluates to what extent, if any, Brexit could provide the UK with greater autonomy to grant state aid. Section A provides a brief overview of the current EU state aid regime. Section B examines possible UK state aid arrangements after Brexit. Section C discusses state aid in the context of a no-deal 'hard' Brexit and compares the state aid law of the World Trade Organisation (WTO) with that of the EU. Section D evaluates the extent to which the law of the WTO would act as a barrier to the UK's ability to grant subsidies to its domestic industry. Section E concludes.

\section{A. THE EU STATE AID REGIME}

The EU state aid regime is established in Articles 107 - 108 TFEU. ${ }^{4}$ Pursuant to Article 107 (1) TFEU, state aid is the grant of governmental assistance which, 'distorts or threatens to distort competition by favouring certain undertakings or in the production of certain goods.' The grant of such aid, 'in so far as it affects trade between Member States,' is incompatible with the internal market and hence prohibited.

While the EU state aid regime would appear to prohibit all types of state aid, it contains a number of exceptions. Under Article 107(2) TFEU, for example, certain types of state aid are deemed to be compatible with the internal market. These include, inter alia, assistance having a social character, granted to individual consumers as well as aid aimed at remediating damage caused by natural disasters. Furthermore, under Article 107(3), the Commission has discretion to determine that other categories of state aid are compatible

* Lecturer in Law, University of Strathclyde. My thanks go to Aileen McHarg and Barry Rodger for their helpful comments. The usual disclaimer applies.

1 European Commission, "EU State Aid Scoreboard 2016" (2016) available at http://ec.europa.eu/competition/state_aid/scoreboard/technical_note_en.pdf.

${ }^{2}$ For a useful overview of these discussions, see A Biondi, "The First on the Flight Home: The Sad Story of State Aid Control in the Brexit Age" (2016) 27 (2) Kings LJ 442 at $442-443$.

${ }^{3}$ See, eg, S Welton, "Freed from the EU's shackles, Brexit Britain can rekindle the regions" (10 April 2017) available at http://www.telegraph.co.uk/news/2017/04/10/freed-eusshackles-brexit-britain-can-rekindle-regions/.

${ }^{4}$ For an overview, see K Bacon, European Union Law of State Aid, $3^{\text {rd }}$ edn (2017).

Edinburgh Law Review (2018) Author Accepted Manuscript 
with the internal market. ${ }^{5}$ There are also a number of block exemptions, including a General Block Exemption Regulation. ${ }^{6}$

The Commission exercises surveillance and supervisory control over state aid and States must notify it of any plans to implement new or alter existing state aid. ${ }^{7}$ The grant of state aid without prior approval is unlawful. ${ }^{8}$ Aid falling under a block exemption does not, however, require notification. Most, though by no means all, state aid is now covered by the General Block Exemption Regulation and does not require prior approval. ${ }^{9}$ Certain other types of aid falling below a de minimis level are also exempt from notification. ${ }^{10}$

The EU state aid regime has been extensively criticised. According to Peretz and Bacon, these criticisms largely fall into three categories: that the Commission has taken an unduly expansive view of what constitutes state aid; that Commission's decisions at times lack transparency and economic rigour; and that the approval process for notified state aid is far from timely. ${ }^{11}$ Such concerns were also expressed in the Coalition Government's balance of competences review. ${ }^{12}$

\section{B. STATE AID AFTER BREXIT}

In the short term, the UK is expected to reproduce EU state aid rules as retained EU law. This is certainly the approach envisaged in the European Union (Withdrawal) Bill. ${ }^{13}$ In the longer term, the shape of state aid disciplines in the UK will depend, at least in part, upon the nature of post-Brexit settlement between the UK and the EU-27. The European Council has underscored that any deal with the UK should establish a 'level playing field' in the area of state aid and competition law. ${ }^{14}$ This concern is apt to result in the EU insisting that state aid provisions are inserted into any agreement with the UK. ${ }^{15}$

\footnotetext{
${ }^{5}$ Under Article 107 (3) (e) TFEU and Article 108 (2), third paragraph TFEU, the Council may extend the categories of aid which may be compatible with the internal market.

${ }^{6}$ Council Regulation 651/2014 declaring certain categories of aid compatible with the internal market in application of Articles 107 and 108 of the Treaty (GBER) OJ 2014 L187/1.

${ }^{7}$ Article 108 (3) TFEU.

${ }^{8}$ For a discussion of the procedures applicable to the investigation of such aid, see Bacon ( $\mathrm{n}$ 4) ch 18.

${ }^{9}$ Bacon (n 4) 153. Note, however, that a summary of the measure must still be forwarded to the Commission; GBER (n 6) para 5.18.

${ }^{10}$ Regulation (EU) 1407/2013 on the application of Articles 107 and 108 of the Treaty on the Functioning of the European Union to de minimis aid OJ 2013 L352/1.

${ }^{11} \mathrm{G}$ Peretz and K Bacon, "Paper on post-Brexit options for State aid" (16 November 2016), available at http://uksala.org/paper-on-post-brexit-options-for-state-aid/ 12 Ibid.

${ }^{13}$ European Union (Withdrawal) Bill 2017, Clauses 3 and 4. See also the Explanatory Notes to the European Union (Withdrawal) Bill, paras 87 and 89.

${ }^{14}$ European Council (Art. 50) guidelines following the United Kingdom's notification under Article 50 TEU (2017) §20.

${ }^{15}$ Biondi (n 2) 450.
}

Edinburgh Law Review (2018) Author Accepted Manuscript 
In reviewing the range of potential deals between the UK and the EU-27, it appears unlikely the UK will pursue a deal with the EU based on membership of the European Economic Area (EEA). This would have largely retained the status quo for state aid within the UK albeit with key differences such as the EFTA Surveillance Authority performing the role of the Commission. Other potential models for a deal are possible and, indeed, have been discussed extensively in the literature. ${ }^{16}$ However, the potential for a no deal 'hard' Brexit remains very real.

In the event of no deal, ${ }^{17}$ the UK will continue to be bound by the rules of the WTO on subsidies. This is because the UK is a Member of the WTO and will remain so after Brexit. By dint of this, the UK is a party to the WTO Agreement on Subsidies and Countervailing Measures (SCM), the purpose of which is to impose multilateral disciplines on subsidies which distort international trade. ${ }^{18}$ Accordingly, even under a no deal scenario, the UK's autonomy in the area of state aid/subsidies post-Brexit will be subject to at least some constraint. The next section elucidates upon the key elements of the WTO SCM.

\section{INTERNATIONAL TRADE LAW AND STATE AID}

The WTO SCM is designed to ensure that, 'commitments centred on the removal of border barriers are not circumvented. ${ }^{19}$ WTO law uses the language of subsidies rather than state aid. A subsidy under WTO law is defined as a financial contribution by the government or a public body. ${ }^{20}$ The financial contribution in question must confer a benefit; ${ }^{21}$ that is, it must make the recipient 'better off' than it would have been without the subsidy. ${ }^{22}$ Furthermore, in order to meet the definition under WTO law, the subsidy in question must be 'specific.' This requires that it is targeted towards certain enterprises, industries or geographical areas. $^{23}$

With two exceptions relating to subsidies contingent upon export and import substitution policies, ${ }^{24}$ WTO law does not prohibit subsidies. Instead, other subsidies as defined under WTO law are considered 'actionable' and may be challenged in the event

${ }^{16}$ See, for example, N Crafts, "Brexit and State Aid" (2017) 33 (1) Oxford Rev of Econ Pol 105. See also Peretz \& Bacon (n 11).

${ }^{17}$ Or indeed a deal which is modelled on the EU - Canada, Comprehensive Economic and Trade Agreement (CETA). This contains provisions on subsidies reflective of WTO law.

${ }^{18}$ WTO Panel Report, Brazil - Export Financing Programme for Aircraft (1999) WT/DS46/R, para 7.26.

19 L Rubini, "WTO Subsidy Laws: The International Regulation of State Aid", in H C H Hofmann and C Micheau (eds), State Aid and the European Union (2016) 469 at 472.

${ }^{20} \mathrm{SCM}$, art 1.1.

21 lbid.

${ }^{22}$ WTO Appellate Body Report, Canada - Measures Affecting the Export of Civilian Aircraft (1999), WT/DS70/AB/R, para 157.

${ }^{23}$ See SCM, art 2.

${ }^{24}$ SCM, art 3. Prohibited subsidies are automatically considered specific; SCM, art 2.3.

Edinburgh Law Review (2018) Author Accepted Manuscript 
they cause 'adverse effects ${ }^{25}$ to the interests of another Member. ${ }^{26}$ Adverse effects include, inter alia, injury to the domestic industry of another Member. ${ }^{27}$

Actionable subsidies causing adverse effects may be challenged multilaterally before the WTO dispute settlement system. ${ }^{28}$ If a subsidy, 'results in adverse effects ...the Member granting or maintaining such subsidy shall take appropriate steps to remove the adverse effects or shall withdraw the subsidy. ${ }^{29}$ Prohibited export and import substitution subsidies may also be challenged multilaterally. A successful challenge will result in a direction to remove the subsidy, 'without delay. ${ }^{30}$

Prohibited and actionable subsidies may also be dealt with unilaterally by the affected Member through the imposition of 'countervailing duties.' A countervailing duty is a 'special duty levied for the purpose of offsetting' the subsidy. ${ }^{31}$ The SCM also sets out notification and transparency obligations owed by Members.

\section{ANALYSIS OF 'THE WTO OPTION'}

As an existing WTO Member, the UK is currently required to abide by the SCM. ${ }^{32}$ Post-Brexit, and in the event that it is no longer under the state aid supervisory infrastructure of the EU, the UK may want to introduce an oversight system to ensure compliance with its WTO subsidies obligations. ${ }^{33}$ Such a system will invariably raise sensitive issues pertaining to devolution because the devolved administrations have extensive spending powers independent of the UK government. ${ }^{34}$ Under the WTO legal regime, the UK is responsible for any acts of the devolved administrations in breach of the SCM. The case for a UK level system of control also connects to the desire to avoid subsidy races between different parts of the UK. ${ }^{35}$

Devolution issues aside, how much scope would there be to do things differently should the UK no longer have to abide by EU or EEA state aid rules? To what extent would WTO law act as a barrier to the UK's ability to grant subsidies to its domestic industry and how does it compare with the EU regime?

\footnotetext{
${ }^{25} \mathrm{SCM}$, art 5 (a) to (c) outlines the types of adverse effects covered by the Agreement.

${ }^{26}$ A third category of subsidy, non-actionable subsidies, is set out in SCM, art 8. This provision was allowed to expire in 2000.

${ }^{27}$ SCM, art 5 on 'adverse effects'. See also SCM, art 6 on serious prejudice.

${ }^{28} \mathrm{SCM}$ art 7.

${ }^{29}$ SCM, art 7.8 .

${ }^{30} \mathrm{SCM}$, art 4.7.

${ }^{31}$ See GATT, art VI.

32 Indeed, more generally, 'both aid granted by Member States and aid granted by the EU itself may be considered a subsidy, and objected (to), under the SCM. This has already happened on several occasions,' see Rubini (n 19) 507.

${ }^{33}$ Crafts (n 16) 107.

34 Peretz \& Bacon (n 11).

35 Ibid.
}

Edinburgh Law Review (2018) Author Accepted Manuscript 
There is considerable commonality between the concept of a subsidy under WTO law and that of state aid under Article 107(1) TFEU. ${ }^{36}$ In respect of both EU and WTO law, for example, some sort of 'benefit' (to use the WTO parlance) or 'economic advantage' (to use the language of the EU state aid regime) is required. ${ }^{37}$ Furthermore, both require some sort of governmental measure. Additionally, the concept of 'specificity' under WTO law is broadly analogous to that of 'selectivity' under EU state aid law. ${ }^{38}$

There are, however, important distinctions between EU and WTO law. There is no distinction in EU law between actionable and prohibited subsidies. There is also no requirement, or indeed scope under WTO law, for prior approval of subsidies. Review of subsidies under WTO law is ex post and reliant on upon another WTO Member bringing enforcement action, whether unilaterally through the imposition of countervailing measures or multilaterally through the WTO dispute settlement system. More broadly, the WTO system is less interventionist in that it sets a higher bar than the EU to the finding of an (actionable) subsidy through the 'taxing requirements' it has in place in respect of, for example, 'adverse effects. ${ }^{39}$

The less interventionist nature of the WTO subsidies regime has led some commentators to claim there may be 'greater scope for selective industrial policy under WTO rules. ${ }^{40}$ Indeed, Crafts argues that the UK government may consider such interventions necessary to address any decrease in foreign direct investment following the UK's exit from the single market. ${ }^{41}$ Previous UK administrations have not, however, performed particularly well when 'picking winners' in industrial policy and there is a high risk of capture and government failure in this regard. ${ }^{42}$ Accordingly, pure self-interest is likely to dictate that the UK will implement a rigorous system of independent review of the grant of state aid/subsidies. ${ }^{43}$ Moreover, while the enforcement system under the WTO SCM regime is undoubtedly laxer than that applicable to state aid under the EU, the plethora of subsidies disputes ${ }^{44}$ which have been litigated at the WTO make it clear that the UK will not have free rein to subsidise domestic industry in the aftermath of Brexit.

${ }^{36}$ D Unterhalter and T Sebastian, "After Brexit: State Aid under WTO Disciplines" (2017) available at http://1exagu1grkmq3k572418odoooym-wpengine.netdna-ssl.com/wpcontent/uploads/2016/09/AFTER-BREXIT.pdf.

${ }^{37}$ Rubini (n 19) 475 . See also Ibid.

${ }^{38}$ For discussion, see Rubini (n 19) 487. See also Unterhalter \& Sebastian (n 36).

${ }^{39}$ see Rubini (n 19) 506. See also Unterhalter \& Sebastian (n 36).

${ }^{40}$ For discussion, see Crafts (n 16) 107.

${ }^{41}$ Ibid at 109.

42 Ibid at 111.

${ }^{43}$ M Schonberg, "Continuity or change? State aid control in a post-Brexit United Kingdom" (2017) 16 (1) Competition Law 47 at 55. The Competition and Markets Authority has been proposed for this task; G Peretz, K Bacon and I Taylor, "Bringing State Aid Home: Could an Effective Domestic State Aid Regime Be Devised for the UK" (2017) available at http://uksala.org/bringing-state-aid-home-could-an-effective-domestic-state-aid-regime-bedevised-for-the-uk/.

${ }^{44}$ For an overview, see Rubini (n 19).

Edinburgh Law Review (2018) Author Accepted Manuscript 


\section{E. CONCLUSION}

The shape of the UK state aid regime post-Brexit will undoubtedly be determined by the nature of the legal relationship between the UK and the EU. The EU has set out quite clearly that any deal with the UK should establish a 'level playing field' in the area of state aid and competition law. ${ }^{45}$ This concern is likely to result in the EU insisting that state aid provisions are inserted into any agreement with the UK. ${ }^{46}$ The potential for no deal, however, remains very real. In the absence of a deal, the UK would remain bound by the provisions of the WTO SCM Agreement. While WTO law is certainly less interventionist than the EU state aid regime, the UK will not have free rein to subsidise domestic industry in the event of a hard Brexit. Furthermore, pragmatic self-interest is likely to result in the UK implementing a rigorous system of independent review of grant of state aid, even in the event of a no deal scenario.

\footnotetext{
${ }^{45}$ European Council guidelines (n 14).

${ }^{46}$ Biondi (n 2) 450.
}

Edinburgh Law Review (2018) Author Accepted Manuscript 